\title{
Hepatitis B Virus Positive
}

National Cancer Institute

\section{Source}

National Cancer Institute. Hepatitis B Virus Positive. NCI Thesaurus. Code C141405.

An indication that hepatitis virus B has been detected in a sample. 